\title{
Nurses' Perception of Patient Rounds - between the Real and the Ideal
}

\author{
Michal Rassin ${ }^{1} \&$ Tamar Kanety ${ }^{2}$ \\ ${ }^{1}$ Nursing Research Unit, Assaf Harofeh Medical Center, Zrifine 70300, Israel \\ ${ }^{2}$ Director of Nursing, Assaf Harofeh Medical Center, Zrifine 70300, Israel \\ Correspondence: Michal Rassin, Nursing Research Unit, Assaf Harofeh Medical Center, Zrifine 70300, Israel
}

Received: September 19, 2017

Accepted: October 17, 2017

Online Published: October 26, 2017

doi:10.20849/ijsn.v2i2.202

URL: https://doi.org/10.20849/ijsn.v2i2.202

\begin{abstract}
Background: Although patient rounds became part of the wards' routine for many years, there are still gaps regarding its tasks, cyclicality and participants and also the round was not backed by clear goals or instructions.

Aim: to examine how nurses perceive rounding in terms of its cyclicality, tasks and participants.

Method: research participants were 181 nurses of the internal, surgery-orthopedic, and maternity wards. They fill a questionnaire containing 41 items, specifically designed for this research. Data was analyzed using descriptive and comparative statistics.

Results: significant differences between nurses from the various wings $(\mathrm{p}=0.000)$ were found in the performance of actual rounding during all shifts. Rounding was performed in the internal wards every two hours and 48 minutes in average, compared with every two hours and 12 minutes in the surgery wards and every hour and 54 minutes in the maternity wards. A gaps were found between real and ideal $(\mathrm{p}=0.000)$, show the ideal timeframe between the rounds were shortened by 10-30 minutes in each shift. The tasks rated as most important in all shifts were: early identification of medical distress situations (respiratory, bleeding, changes in conciseness etc.), taking actions to avoid complications including identifying a malfunctioning transfusion, position changes, answering patient questions, pain assessment and treatment, and answering basic needs.

Conclusions: A policy for the performance of rounding, may bridge the gap between real and ideal and promote the quality of nursing care will provide clear guidance as to its tasks, cyclicality and participants.
\end{abstract}

Keywords: patient rounds, proactive rounding, tasks, shifts

\section{Introduction}

patients rounds is a process in which nurses visit in hospital patients in a cyclicality of regular time period, in order to answer their needs and perform basic nursing treatment, such as: aid in going to the lavatory, position change, providing beverages and other tasks (Beverly; Bartley; Cornwell, 2011; Tea; Ellison \& Feghali, 2008; Baker, 2012), Previous studies reported that initiated rounding with regular intervals decreased patient's falls, bedsores, and ringing the nurse, as well as contributed to an increase in patient satisfaction of the nursing treatment (Graci, 2013; Dean, 2012; Meade, Bursell \& Ketelsen, 2006).

Rounding is not a new concept. It was first mentioned in the book "Notes on Nursing" by Florence Nightingale. She stated that the nurse should perform patient rounds to ensure that their environment contributes to their recuperation. Over the years, nurses have performed initiated rounds, in which attention was especially focused on checking skin integrity and preventing bedsores (Neils, 2010).

Although nurse rounding became part of the wards' routine, it was not backed by any clear goals or instructions, apart from the inherited belief that it enables a better bond with the patients and improves their sense of comfort. Recently, the topic has returned to the agenda due to the recognition of the importance of patient experience as a key aspect in treatment quality. This notion was accompanied by the significant increase in medical technologies based treatments that has led to the reduction in performing basic activities by nurses, which in time were handed to less professional teams. Consequently, nurses were accused by preforming less patients' bed side visits and that human contact as a part of their work became narrowed (doyle, 2009; Beverley, Bartley\& Cornwell, 2011).

Research evidences revealed that patients perceive nursing treatment quality according to the nurse's availability and the way their basic needs were fulfilled far binned the professional skills demonstrated by the nurse (Meade; 
Bursell \& Ketelsen, 2006). Recognizing the importance of nursing in patients' experience and expectations for more nurse-time refocused attention to the nurses' rounding's and the need to maintain and strengthen basic nursing work alongside complex nursing treatment.

Rounding is performed in all wards, units, and emergency rooms according to the common approach as to the round's essence and its goals. As so, the rounding varies in terms of times, shifts, wards, participants and tasks. One of the most reported rounding approaches in the world is called "intentional rounding". The rounding is performed in a cyclicality of an hour to two hours according to a defined goal, which is to promote patients' safety and fulfill their basic needs (Dean, 2012; Meade, Bursell \& Ketelsen, 2006). Rounding is performed by a registered nurse accompanied by a practical nurse or a nurses' aid, according to the P's protocol. This protocol includes pain examination and intervention, position change to prevent bedsores and increase comfort, potty aid in going to the lavatory or providing a panlbottle, as well as examining the existence of vital items in the patient's possession, such as: bell, telephone, tissue paper, water etc. An additional $\mathbf{P}$ instructs asking the patients whether they need anything else, while emphasizing that the personnel has time and will return for another round in an hour (promise). Before leaving the room, the nurse documents the time and the actions performed in a form hanging in the room and verifies the round with their signature (Dean, 2012; Meade, Bursell \& Ketelsen, 2006).

Thus, the aim of this study was to examine how nurses perceive rounding in terms of its cyclicality, tasks and participants, while comparing the reality to the desirable. Based on the study's findings, a uniform policy of rounding performance could be suggested.

\section{Method}

\subsection{Participants}

The study included 181 nurses from the internal wing (58\%), surgery-orthopedic wing (22.5\%), and maternity wing that included maternity and high-risk pregnancy wards (19.5\%). Average age was 42.57 years $(\mathrm{SD}=8.4)$. There was female dominance (89.4\%); $40 \%$ were native Israelis and 54\% immigrants from the Commonwealth of the Independent States; $55.2 \%$ were university graduates registered nurses, $32.6 \%$ were non university graduates registered nurses, and $10.3 \%$ were practical nurses. Average seniority was 17 years $(\mathrm{SD}=12.4)$. No significant differences between the groups of nurses from the various wings were observed regarding age, ethnicity, education and seniority.

\subsection{Research Tools}

In the absence of previous research tools, a special questionnaire was designed for the research, based on a literary screening and professional experience. Questionnaire items were classified into three main content files matching the research questions. The first part examined the actual rounding frequency during the various shifts, and its ideal frequency (comparing real with ideal). The second part of the questionnaire asked respondents to rate the various tasks performed during rounding, according to importance. A focus group of 6 nurses from internal, surgery, and maternity wings was designed in order to assemble the task list, performed during rounding (e.g. position change, aid in going to the lavatory, cleaning the surroundings etc.). Task importance was rated on a scale of three levels, level 3 defined as the most important and level 1 defined as less important. An open question was added to the questionnaire, in which participants were asked to specify the factors promoting or inhibiting rounding performance. Evaluation of the questionnaire content validity was conducted by an expert group that included 3 supervising nurses, who examined the suitability of the questionnaire to the research questions. In addition, they were asked to gather tasks with a common identity into categories and define them. Categories were: 1. Early identification of medical distress situations (respiratory, bleeding, conciseness changes); 2. Taking actions to avoid complications (handling transfusions, position changes, bell); 3. Pain and comfort assessment; 4. Fulfilling basic needs (aid in going to the lavatory, diaper changing, providing beverages \food); 5. Communication and answering questions; 6. Environmental safety. 6. Hotelier (bed making). Internal reliability of the alpha Cronbach index throughout the questionnaire ranged between 0.6 and 0.9 . To test the questions' clarity, they were forwarded as a pilot to 15 participants and amended in response to their remarks.

\section{Data Analysis}

Averages were calculated for all items in the questionnaire on the single factor level, and an ANOVA test was performed to compare the groups of nurses of the various wings.

\section{Findings}

Significant differences between the three groups $(\mathrm{p}=0.0001)$ were found in the actual rounding performance frequency, in all shifts (real). During morning shift, rounding was performed in the internal wing every two 
hours and 48 minutes in average, compared with every two hours and 12 minutes in the surgery wing and every hour and 54 minutes in the maternity wing. Rounding was performed in the evening every three hours and 25 minutes, and at night every three and a half hours in the internal wing, while in the surgery and maternity wings the rounding was performed during the evening and night shifts every two hours and 45 minutes on average with no differences between both shifts.

When participants were asked what they considered to be the ideal rounding frequency during the various shifts (as opposed to the previous question that referred to actual performance), significant differences were notes between real and ideal $(\mathrm{p}=0.000)$, as well as between the groups. In the internal and surgery wings a desire to shorten the ideal timeframe, by a range of 10-30 minutes during all shifts, between rounding's was raised, while in the maternity wing, nurses believed the ideal timeframe between rounds should be longer than actually performed.

Table 1. Patient rounding frequency - real versus ideal (data is shown in hours and minutes)

\begin{tabular}{|c|c|c|c|c|c|c|c|}
\hline shift & time & $\begin{array}{l}\text { General } \\
\text { average }\end{array}$ & $\begin{array}{l}\text { Internal } \\
\text { wing }\end{array}$ & $\begin{array}{l}\text { Surgery } \\
\text { wing }\end{array}$ & $\begin{array}{l}\text { Maternity } \\
\text { wing }\end{array}$ & $\mathbf{F}$ & $\mathbf{P}$ \\
\hline \multirow[t]{2}{*}{ Morning } & $\begin{array}{l}\text { Actual } \\
\text { rounding } \\
\text { time }\end{array}$ & 2.30 & 2.48 & 2.12 & 1.54 & 13.78 & 0.000 \\
\hline & $\begin{array}{l}\text { Ideal } \\
\text { rounding } \\
\text { time }\end{array}$ & 2.24 & 2.42 & 2 & 2 & 10.1 & 0.000 \\
\hline \multirow[t]{2}{*}{ Evening } & $\begin{array}{l}\text { Actual } \\
\text { rounding } \\
\text { time }\end{array}$ & 3 & 3.24 & 2.36 & 2.18 & 21 & 0.000 \\
\hline & $\begin{array}{l}\text { Ideal } \\
\text { rounding } \\
\text { time }\end{array}$ & 2.48 & 3 & 2.12 & 2.30 & 15.6 & 0.000 \\
\hline \multirow[t]{2}{*}{ Night } & $\begin{array}{l}\text { Actual } \\
\text { rounding } \\
\text { time }\end{array}$ & 3.12 & 3.30 & 2.54 & 2.48 & 12 & 0.000 \\
\hline & $\begin{array}{l}\text { Ideal } \\
\text { rounding } \\
\text { time }\end{array}$ & 3 & 3.18 & 2.18 & 2.48 & 15.1 & 0.000 \\
\hline
\end{tabular}

The second research question examined was which of the tasks performed during rounding's is more important throughout the various shifts. The task rated by all of the nurses participating in the research as most important, in all shifts, was early identification of medical distress situations (respiratory, bleeding, etc.). The task rated second most important during all shifts was taking actions to avoid complications, such as: handling malfunctioning transfusions and position changes, which, as expected, was rated low in the maternity wing treating independent women. Checking that the bell functions and is near the patients was also rated high throughout the shifts and by all participants. Answering patient's questions was rated high, especially during the morning and evening shifts and, as expected, lowers during the night shift.

Pain assessment was rated high during all shifts, and lower, as expected, at night. Checking patient surroundings for anything related to cleanliness and safety was rated next, followed by fulfilling basic needs, such as: beverage, food, diaper change, escorting patients to the lavatory, providing a pan $\backslash$ bottle, that were rated relatively lower than the other categories. The task rated last in terms of importance was making patient beds. 
Table 2. Tasks rating during the morning shift - wings comparison

\begin{tabular}{|c|c|c|c|c|c|c|}
\hline Category & Task & $\begin{array}{l}\text { General } \\
\text { average }\end{array}$ & $\begin{array}{l}\text { Internal } \\
\text { wing }\end{array}$ & $\begin{array}{l}\text { Surgery } \\
\text { wing }\end{array}$ & $\begin{array}{l}\text { Maternity } \\
\text { wing }\end{array}$ & $\mathbf{P}$ \\
\hline $\begin{array}{l}\text { Early } \\
\text { identification of } \\
\text { medical distress } \\
\text { situations }\end{array}$ & $\begin{array}{l}\text { Respiratory distress, } \\
\text { bleeding, } \\
\text { consciousness drop }\end{array}$ & 3 & 3 & 3 & 3 & N.S \\
\hline \multirow{3}{*}{$\begin{array}{l}\text { Actions to avoid } \\
\text { complications }\end{array}$} & Transfusion check & 2.97 & 2.98 & 2.94 & 2.96 & N.S \\
\hline & Position change & 2.81 & 2.91 & 2.85 & 2.4 & 0.000 \\
\hline & bell & 2.94 & 2.91 & 2.96 & 3 & N.S \\
\hline $\begin{array}{l}\text { Communicating } \\
\text { and answering } \\
\text { questions }\end{array}$ & Answering questions & 2.97 & 2.96 & 2.97 & 3 & N.S \\
\hline \multirow[t]{2}{*}{ Pain and comfort } & Pain check & 2.92 & 2.91 & 2.94 & 2.93 & N.S \\
\hline & Comfort & 2.88 & 2.92 & 2.75 & 2.90 & N.S \\
\hline $\begin{array}{l}\text { Environmental } \\
\text { safety }\end{array}$ & $\begin{array}{l}\text { Patient's environment } \\
\text { is clean and dry }\end{array}$ & 2.81 & 2.87 & 2.75 & 2.7 & N.S \\
\hline \multirow[t]{3}{*}{$\begin{array}{l}\text { Answering basic } \\
\text { needs }\end{array}$} & $\begin{array}{l}\text { Diaper } \\
\text { changelprovisions of } \\
\text { a pan-bottle }\end{array}$ & 2.75 & 2.76 & 2.79 & 2.64 & N.S \\
\hline & $\begin{array}{l}\text { Providing } \\
\text { beveragelfood }\end{array}$ & 2.72 & 2.73 & 2.72 & 2.68 & N.S \\
\hline & $\begin{array}{l}\text { Aid in going to the } \\
\text { lavatory }\end{array}$ & 2.69 & 2.72 & 2.79 & 2.46 & N.S \\
\hline Hotelier & Making beds & 2.63 & 2.64 & 2.68 & 2.54 & N.S \\
\hline
\end{tabular}

The third research question checked which nursing staff members should participate in patient rounds. Data showed that a registered nurse in charge of the patients and another nurse (especially a new nurse) should attend the rounding. The participants rated in the third and fourth places were a practical nurse and a nurses' aid :

Table 3. Who should participate in the round

\begin{tabular}{llllll}
\hline Participants & $\begin{array}{l}\text { General } \\
\text { average }\end{array}$ & $\begin{array}{l}\text { Internal } \\
\text { wing }\end{array}$ & $\begin{array}{l}\text { Surgery } \\
\text { wing }\end{array}$ & $\begin{array}{l}\text { Maternity } \\
\text { wing }\end{array}$ & P \\
\hline $\begin{array}{l}\text { Nurse in } \\
\text { charge }\end{array}$ & 3.85 & 3.81 & 3.87 & 3.93 & N.S \\
\hline $\begin{array}{l}\text { New nurse } \\
\begin{array}{l}\text { Practical } \\
\text { nurse }\end{array}\end{array}$ & 3.84 & 3.83 & 3.81 & 3.93 & N.S \\
\hline $\begin{array}{l}\text { Registered } \\
\text { nurse }\end{array}$ & 3.74 & 3.65 & 3.78 & 3.87 & 0.05 \\
\hline $\begin{array}{l}\text { Nurses' aid } \\
\text { Shift manager }\end{array}$ & 3.7 .42 & 3.86 & 3.65 & 3.32 & 0.001 \\
nurse & 3.23 & 3.6 & 3.84 & 0.000 \\
\hline $\begin{array}{l}\text { Senior staff } \\
\text { nurse }\end{array}$ & 3.39 & 3.24 & 3.5 & 3.7 & N.S \\
\hline Head nurse & 2.71 & 2.4 & 2.7 & 3.5 & 0.000 \\
\hline $\begin{array}{l}\text { National } \\
\text { service girl }\end{array}$ & 1.4 & 1.3 & 1.2 & 2.2 & 0.000 \\
\hline
\end{tabular}


Answers to the open question, in which participants were asked to name promoting or inhibiting factors to rounding, yielded the following representative quotes:

* Rounding meets patients' needs and increases their satisfaction. Knowing that patient received a quality care and that all the necessary nursing treatment was conducted gives the nurse a "peace of mind".

* Rounding fulfills patients' basic needs, prevents complications and enables access to patients that cannot call a nurse, such as disabled, bedridden patients, or patients that do not complain.

* Intentional rounding monitor's patient status, one gets to know them better, enables identification of complaints and problems in real time and prevent complications (bedsores, falls, and respiratory problems). In general, the higher the rounding frequency, the more one can identify problems in time.

* Patients are monitored and their nursing and medical needs are taking care of without them asking for it. This grants patients a sense of safety and care, improves treatment quality, as well as patient's physical safety.

Alongside rounding benefits, participants presented the following inhibiting factors:

* The reality in the ward is that there is not enough manpower. Sometimes, not all tasks are completed in time and that takes away from rounding length.

* A chronic lack of nursing staff. In general, a limited staff against multiple tasks.

* Work overload, multiple admissions and discharges, multiple forms taking up valuable time.

* Increased paperwork, many complex patients requiring prolonged treatment time, lack of staff in almost every shift, resuscitations, and many visitors interrupting the ward's current activity.

* Complex patients, patient status deterioration, unexpected urgent activity, such as resuscitation, take up a lot of time at the expense of the round.

* Despite inhibiting factors, especially interesting was the next quote, attesting to the round's great importance:

* The internal wards are constantly overloaded, which prevents rounding in the ideal frequency, but rounding is nevertheless part of a ward routine as important as, for example, medication.

\section{Discussion}

The general trend arising from the present study is that the round's first goal is to prevent medical distress situations, by early identification. Taking actions to avoid complications were rated as most important, while fulfilling patents personal needs were rated as less important tasks during rounding.

Previous studies that examined rounding goals and tasks pointed out the patient comfort and safety promotion, as well as providing patients and family members with information (Dean, 2012; Graci, 2013; Neils, 2010). Beverley, Bartley \& Cornwell (2011) identified the round's key goals and tasks as communicating with the patient, pain management as well as room and bathroom cleanliness. During rounding, nurses address pain, position and comfort needs, offer patients help in eating, going to the lavatory, and check that all of the items required by the patients are within their reach (Beverley, Bartley\& Cornwell, 2011). Thus, the conclusion is that all of the round's goals and tasks described in the current and previous studies were aimed, directly or indirectly, at maintaining patients' safety and addressing their basic needs.

Several reports have drawn attention to the scarcity of "basic nursing treatment" standards - meeting patient needs, regarding: feeding, positioning, bodily waste and personal hygiene. Moreover, research evidences revealed that more nurse time with the patient leads to better treatment results, especially a decrease in the number of falls, in bedsores and an improvement in patient experience. Cyclic rounding can significantly change patients' perception of the treatment's efficiency they have received, and the fulfillment of their safety needs (Doyle, 2009; Weisgram \& Raymond, 2008; Beverley, Bartley \& Cornwell, 2011). Thus, some hospitals around the world have adopted the nursing staff's responsiveness to the patient's basic needs as a nursing quality standard (Dean, 2012). In the current treatment environment, spending more time with the patient poses a challenge. As demonstrated in the current study's findings, lack of staff, a multitude of patients and overload of nursing tasks prevents the performance of the rounding's in the desired ideal frequency. There are many evidences of patients reporting of "a busy staff with no time", thus hesitating to ask the staff for help, which might harm their safety. Nurses also report frequently about lack of time and multitude tasks that keep them from properly treating their patients resulting with accumulation of frustration (Meade, Bursell \& Ketelsen, 2006; Beverley; Bartley \& Cornwell, 2011; Meade; Bursell \& Ketelsen, 2006; Graci, 2013). One of the tasks posing high time and energy demands on the nurse is a frequent response to patient calls, occurring while focusing on 
additional tasks, such as medicine distribution. The outcome may result in treatment errors.

The high pressure and overload enforce the nurses to take care of urgent arising problems rather than to design and organize the work order in advance. As a result, the patient's need is addressed passively upon appealing for help, rather than an initiating approach according to the proactive rounding method. Thus, the nurse should appeal to the patients and verify their needs when present in their room during the rounds and not wait for them to approach to satisfy their needs.

While doing so the nurse should present the patients with leading questions, such as: "are you in pain" and "do you need something else" prior to leaving the room. Research findings revealed that proactive rounding with an hour to two hours' frequency lead to a $65 \%$ decrease in nurse bell calls. Consequently, it significantly decrease interruptions to the nurse's work and created a good, calm atmosphere amongst patients and their families. Reports from the current study's participants showed that rounding provides the nurses with "peace of mind" and a feeling that they have given the patients good, professional, qualitative, and timely service. These findings correlate previous studies that described rounding benefits as decreasing pressure on nurses and enabling them quiet breaks with no bells and patient calls (Olrich, Kalman \& Nigolian, 2012; Duffin, 2010; Halm, 2009; Neville, Lake, LeMunyon, Paul \& Whitmore, 2012; Rondinelli, Ecker, Crawford, Seelinger \& Omery, 2012; Wright \& McSherry,2013).

\section{Recommendations}

Based on the current study findings and the surveyed literature it seems that rounding throughout the shifts promotes patients' safety and fulfillment of their basic needs, therefore the following recommendations are presented:

-Rounding goals and tasks should be defined and clarified to the nursing staff performing them.

-It seems that nurses may not have been engaging in proactive rounding; therefore proactive rounding approach should be established- meaning an initiated approach to the patients with questions and addressing their basic needs prior to their request.

-Rounding will be performed in a 2-3 hours' cyclicality while striving for shorter timeframes. However, rounding approach should be flexible and adaptable to local circumstances.

-Staff should observe all patients in the room and identify, if any, medical distress situations, such as: changes in consciousness, respiratory distress, bleeding - and intervene.

-Staff should take actions to avoid complications, such as: position change, diaper change, making sure transfusions function.

-Staff should initiate an approach to the patients and ask them whether they are in pain or uncomfortable, offer help in going to the lavatory or a pan lbottle. Regarding pain - an intervention should be performed accordingly (position change to alleviate pressure, consulting the treating physician in order to medicate). If the patient complains about discomfort, staff should take actions to improve the situation according to patient needs, such as another pillow or blanket and help with a position change. While the staff performs those actions, they should explain to the patient and their family what they are doing and why. For instance, "I am changing your position so that you would be more comfortable and to make sure your skin stays intact and no bedsores will evolve as result of prolonged pressure on the same spot."

-Staff should make sure all of the items the patients require are within their reach, such as: bell, telephone, TV remote, night light switch, bedside table, tissue paper, water etc.

-Staff should answer patient questions according to their ability, and forward requests to other staff members.

-Staff should check for environmental obstacles and remove them (wet floor, equipment items hindering passage and so on).

-Before leaving the room, the nurse should finish the round with a closing statement - "is there anything more I can do for you?" This statement could aid those patients who are shy, avoid asking, or afraid to ask knowing the staff is busy.

\section{References}

Baker, S.J. (2012). Hourly rounding in the emergency department: how to accelerate results. Journal of Emergency Nursing, 38(1), 69-72. https://doi.org/10.1016/j.jen.2011.09.013

Beverley, F., Bartley, A., \& Cornwell, J. (2011). Intentional rounding: its role in supporting essential care. Nursing Times, 107, 27. 
Dean, E. (2012). Regular ward checks raise standards of care. Nursing Management, 19(2), 12-6. https://doi.org/10.7748/nm2012.05.19.2.12.c9063

Doyle, S. (2009, March 3). Hourly nurse rounding is growing trend around the country. The Huntsville Times. Retrieved from http://www.al.com/living/huntsvilletimes/index.ssf?/base/living/1236075393156810.xml\&coll=1

Duffin, C. (2010). Hourly ward rounds improve care and reduce staff stress. Nursing Management, 17(7), 6-7. https://doi.org/10.7748/nm.17.7.6.s6

Graci, A. (2013). A rounding system to enhance patient, parent, and neonatal nurse interactions and promote safety. Journal of Obstetric, Gynecologic and Neonatal Nursing, 42, 239-242. https://doi.org/10.1111/1552-6909.12011

Halm, M. A. (2009). Hourly rounds: what does the evidence indicate? American Journal of Critical Care, 18, 581-584. https://doi.org/10.4037/ajcc2009350

Meade, C. M., Bursell, A., \& Ketelsen, L. (2006). Effects of nursing rounds on patients' call light use, satisfaction and safety. American Journal of Nursing, 106(9), 58-70. https://doi.org/10.1097/00000446-200609000-00029

Neils, P. E. (2010). The influence of Nightingale rounding by the liaison nurse on surgical patient families with attention to differing cultural needs. Journal of Holistic Nursing, 28, 235. https://doi.org/10.1177/0898010110368862

Neville, K., Lake, K., LeMunyon, D., Paul, D., \& Whitmore, K. (2012). Nurses' perception of patient rounding. The Journal of Nursing Administration, 42(2), 83-88. https://doi.org/10.1097/NNA.0b013e318243365e

Olrich, T., Kalman, M., \& Nigolian, C. (2012). Hourly rounding: a replication study. Medsurg Nursing, 21(1), 23-6, 36.

Orr, N., Tranum, K., \& Kupperschmidt, B. (2006). Hourly rounding for positive patient and staff outcomes: fairy tale or success story? American Journal of Nursing, 106(9), 58-70.

Rondinelli, J., Ecker, M., Crawford, C., Seelinger, C., \& Omery, A. (2012). Hourly Rounding Implementation: A Multisite Description of Structures, Processes, and Outcomes. The Journal of Nursing Administration, 42, 326-332. https://doi.org/10.1097/NNA.0b013e31824ccd43

Tea, C., Ellison, M., \& Feghali, F. (2008). Proactive patient rounding to increase customer service and satisfaction on an orthopaedic unit. Orthpedic Nursing, 27, 233-240. https://doi.org/10.1097/01.NOR.0000330305.45361.45

Weisgram, B., \& Raymond, S. (2008). Using evidence- based nursing rounds to improve patient outcomes. MEDSURGM Nursing, 17(6), 429-430.

Wright, S., \& McSherry, W. (2013) How much time do nurses spend on patient care? Nursing Times, 109, Retrieved $8.6 .2014 \quad$ from http:/www.nursingtimes.net/Journals/2013/08/09/h/h/q/140813-How-much-time-do-nurses-spend-on-patie nt-care.pdf

\section{Copyrights}

Copyright for this article is retained by the author(s), with first publication rights granted to the journal.

This is an open-access article distributed under the terms and conditions of the Creative Commons Attribution license (http://creativecommons.org/licenses/by/4.0/). 